\title{
StRATEgIES FOR MEETING RURAL LEGAL NEEDS: LESSONS FROM LOCAL, REGIONAL AND INTERNATIONAL EXPERIENCE
}

\section{KIM ECONOMIDES*}

This paper considers policy options for future planning of legal services in rural and remote areas and assesses the relative merits of the public and private sectors in identifying and meeting legal needs in such areas. Drawing on previous research and a range of national and international experience I focus on the future development of proactive services in legal service delivery: first, through examining the idea of 'rural law (community) centres' employing salaried lawyers and 'paralegals' working in the public sector; second, through speculating on the implications of emerging alternative business structures and new technology currently evolving in the private sector. The paper evaluates various delivery models (and their likely impact) and considers whether strategic approaches are possible when rural communities are so often dispersed, isolated and politically marginal. It examines the concept and practice of 'rural proofing', as developed by policymakers in the United Kingdom and New Zealand, in order to see whether legal services policy can be better attuned to the needs and expectations of rural communities.

\section{INTRODUCTION}

This paper seeks to identify policy options for future planning of legal services in rural and remote areas and assesses the relative merits of the public and private sectors in identifying and meeting legal needs in such areas. Drawing on previous research and a range of national and international experience, I focus on the future development of proactive services in legal

* Professor of Law, Director, University of Otago Legal Issues Centre, New Zealand $<$ http://www.otago.ac.nz/law/staff/kim_economides.html $>$. I should like to dedicate this paper to the memory of my friend and research collaborator Professor Mark Blacksell (http://www.rgs.org/NR/rdonlyres/E329DF5A-1C8B-4214-B3D2-10EEFC00EF59/7940/ MarkBlacksellObituary4.pdf). 
service delivery: first, through examining the idea of 'rural law (community) centres' employing salaried lawyers and 'paralegals' working in the public sector; second, through speculating on the implications of emerging alternative business structures and new technology currently evolving in the private sector. The paper evaluates various delivery models (and their likely impact) and considers whether strategic approaches are possible when rural communities are so often dispersed, isolated and politically marginal. It examines the concept and practice of 'rural proofing', as developed by policymakers in the United Kingdom and New Zealand, in order to see whether legal services policy could be better attuned to the future needs and expectations of rural communities.

\section{The Rural law Centre: Public Planning of RURAL LEgal SERVICES}

Law centres - or community legal centres - provide a free and independent professional legal service to people who live or work in their catchment areas and supplement or complement judicare. ${ }^{1}$ Those working in law centres are not all qualified lawyers. According to the UK Law Centres' Federation:-

They [law centres] were to set up to overcome the obstacles faced by people who need access to the legal system. Free, publicly provided legal advice should be available to everyone, not just to those with financial resources or to those few that can get legal aid because of their income, there are [sic] many areas of law where legal aid is simply not available. This means that even in areas where fundamental rights are in dispute there is no access to the legal system. Legal aid is not available, for example, for representation at Industrial Tribunals or Immigration Appeals Tribunals.

Law Centres are managed democratically by individuals and organisations from their local areas. They work closely with their communities and provide the kind of services that are most suitable for that area. This accountability means that they complement the services of other community groups and advice agencies in the area, ensuring that there is no duplication

\footnotetext{
1 'Judicare' or the 'compensated private counsel model' of legal aid is a system whereby legal aid is established as a matter of right for all persons eligible under the statutory terms, with the state paying the private lawyer who provides those services. See further Mauro Cappelletti and James Gordley, 'Legal Aid: Modern Themes and Variations' (1972) 24 Stanford Law Review347; Kim Economides, 'Franchising and Rural Legal Services' in David Nelken and Alberto Febbrajo (eds), European Yearbook in the Sociology of Law (Giuffrè, 1993) 262-8.
} 
of work and providing the local groups with back-up legal advice when needed. ${ }^{2}$

Community law centres offer excellent value for money and are able to address legal needs that often are not met by the private profession as they have the ability to specialise in uneconomic areas of legal work. The Benson Royal Commission on Legal Services noted this as far back as 1979:

The impact of Law Centres has been out of all proportion to their size, the number of lawyers who work in them and to the amount of work it is possible for them to undertake. The volume of work they have attracted has shown how deep is the need they are attempting to meet. ${ }^{3}$

The public sector offers the possibility of a more focused and cost-effective legal service and avoids many of the limitations of the private sector. This is true of both civil and criminal legal aid. Different law centres may adopt different policies regarding the individual client though all will attempt to work with the community to tackle underlying structural problems that transcend individual conflicts. Some law centres operate a 'closed door' policy and refuse to solve individual legal problems, working instead with local groups and tenants' associations. Others combine a mix of 'group' and 'individual' work that is determined by a local management committee consisting of representatives from community-based organisations. This model is generally regarded as a more cost-effective means of delivering legal services to the poor, but the disadvantage as compared with the private sector is that such law centres are limited in number and concentrated in deprived areas of inner cities, and so may remain inaccessible to the disabled and those living in rural areas. Law centres have pioneered innovative methods for delivering legal services and, ideally, should complement private legal services supported by judicare. Public legal services can overcome some but not all of the limitations of the private profession that is inevitably subject to the constraints of the market economy. The public sector or salaried legal services offer certain advantages over the private profession when it comes to legal services delivery. The main one is that they can specialise in uneconomic areas of legal work in geographical areas, such as rural, remote or coastal communities, with underdeveloped or seasonal local economies.

\footnotetext{
${ }^{2}$ Law Centres - Free and Independent Professional Legal Services (25 July 2011) Focus on Disability $<\mathrm{http}: / / \mathrm{www}$.focusondisability.org.uk/law-centre.html>.

${ }^{3}$ History and Funding of Law Centres, Law Centres Federation <http://www.lawcentres. org.uk/lawcentres/detail/history-and-funding-of-law-centres/>.
} 
The recent Bazley Review of legal aid in New Zealand noted the cost effectiveness and efficiency of Community Law Centres, and funding has been committed to them in the Legal Services Bill currently before the NZ Parliament. ${ }^{4}$ However, rural law centres have not been developed, in part because of the absence of 'urban communities' that sustain and direct the work of the law centre.

In the early 1980s policy options were identified for rural law centres: a) private model; b) secondment model; c) urban model; d) technological model; e) satellite model; and f) peripatetic model. ${ }^{5}$ Twenty years later the Devon Law Centre came into being in the UK and a proposal was made for it to operate a peripatetic bus that would tour communities in rural Devon (see Fig 1). ${ }^{6}$ This model was never actually implemented in Devon, though one was set up in Cumbria, and Oslo law students did use a 'Juss Buss' to deliver legal services from a similar trailer to both disadvantaged individuals and groups in that city. The model illustrates the kind of proactive approach to legal service delivery possible in rural communities.

\footnotetext{
${ }^{4}$ See Legal Aid Review, Improving the Legal Aid System: A Public Discussion Paper (2009) Ministry of Justice (NZ) <http://www.justice.govt.nz/policy/justice-system-improvements/ legal-aid/legal-aid-review/legal-aid-review-discussion-paper.pdf $>$; Legal Aid Review, Transforming the Legal Aid System: Final Report and Recommendations (2009) $<$ http://www.justice.govt.nz/publications/global-publications/t/transforming-the-legal-aidsystem/transforming-the-legal-aid-system-final-report-and-recommendations-1/at_download/ file>. For an evaluation of the report see Kim Economides, 'Reforming Legal Aid' [2010] NZLJ 5. For the Bill see Legal Services Bill: <http://www.parliament.nz/NR/rdonlyres/ 8695F38F-929D-44F9-8C1D-B6FAF759181E/157050/1800LegalServices1.pdf>. For a submission by the author on the Legal Services Bill to the NZ Justice and Electoral Committee see $<$ http://www.parliament.nz/en-NZ/PB/SC/Documents/Evidence/2/6/4/49SCJE EVI_00DBHOH_BILL10114_1_A138907-Professor-Kim-Economides.htm>.

${ }^{5}$ Kim Economides, 'Legal Services and Rural Deprivation' (1982) 15 Bracton Law Journal 41, 61-5 (also published in (1982) 11(3) Rural Advocacy (Rural Advocacy Group, July 1982)). See also Lord Chancellor's Department, $33^{\text {rd }}$ Legal Aid Annual Report (1982-3) para 184. See also United Kingdom, Parliamentary Debates, House of Commons, 23 March 2004, vol 419, cols $185 \mathrm{WH}-204 \mathrm{WH}$.

${ }^{6}$ Kim Economides, 'Devon Law Bus' (2003) Legal Action 9, 9-10. A similar bus operates in the Philippines: <http://ma2j.wordpress.com/2011/05/18/justice-on-wheels-programme-inthe-philippines/>.
} 


\section{Fig 1: Devon Law Bus}

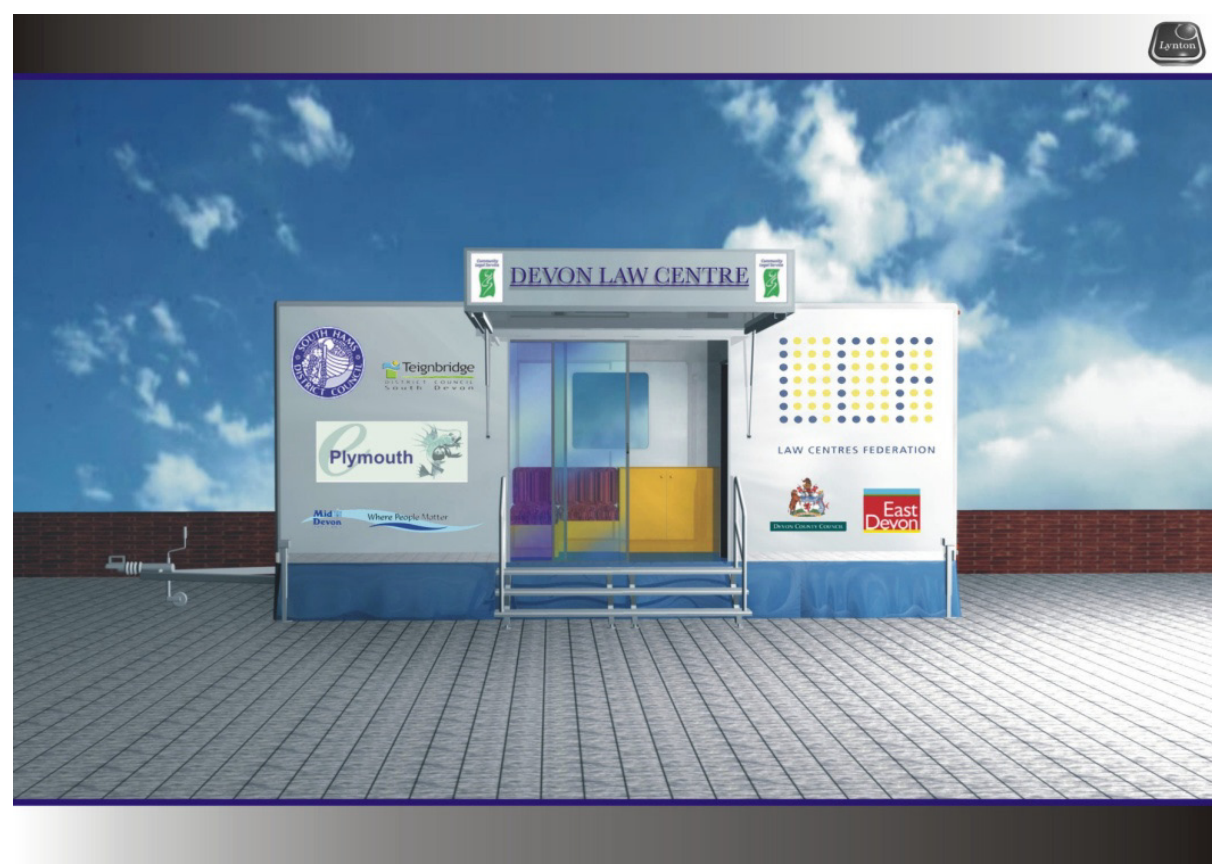

Author of image: Roger Haworth

Another example of proactive 'peripatetic' or 'itinerant' public legal services can be found in Brazil where a boat takes court and legal services to citizens living in remote parts of the Amazon (see Fig 2 below). ${ }^{7}$ The boat 'Tribuna' is in effect a travelling small claims court that also dispenses legal advice. It would also be possible to deliver legal services to remote regions via small aircraft, as happens in the northern territories of Canada, ${ }^{8}$ where teams of lawyers, together with a judge, are flown into isolated communities, analogous to the 'Flying Doctor' in Australia and New Zealand. ${ }^{9}$

7 See Shawn Blore, 'Justice in a Water World: The Law of the Amazon Jungle' The Independent (online) 25 January $2006<\mathrm{http}$ ://www.independent.co.uk/news/world/americas/ justice-in-a-water-world-the-law-of-the-amazon-jungle-524430.html $>$. See also $<$ http://www. mundolegal.com.br/?FuseAction=Noticia_Detalhar\&did=13629>.

${ }^{8}$ Public Prosecution Service of Canada, Annual Report 2009-10 (2010) <http://www.ppscsppc.gc.ca/eng/pub/ar10-ra10/03.html $>$.

9 Wikipedia, Royal Flying Doctor Service of Australia <http://en.wikipedia.org/wiki/ Royal_Flying_Doctor_Service_of_Australia>; Bulls Flying Doctor Service Ltd, The Flying Doctor Service <http://www.flyingdoctor.co.nz/flying-doctor-service>. The current Chief Justice of the High Court of Australia experienced practice as a 'flying lawyer' early in his 


\section{Fig 2: The 'Tribuna'}

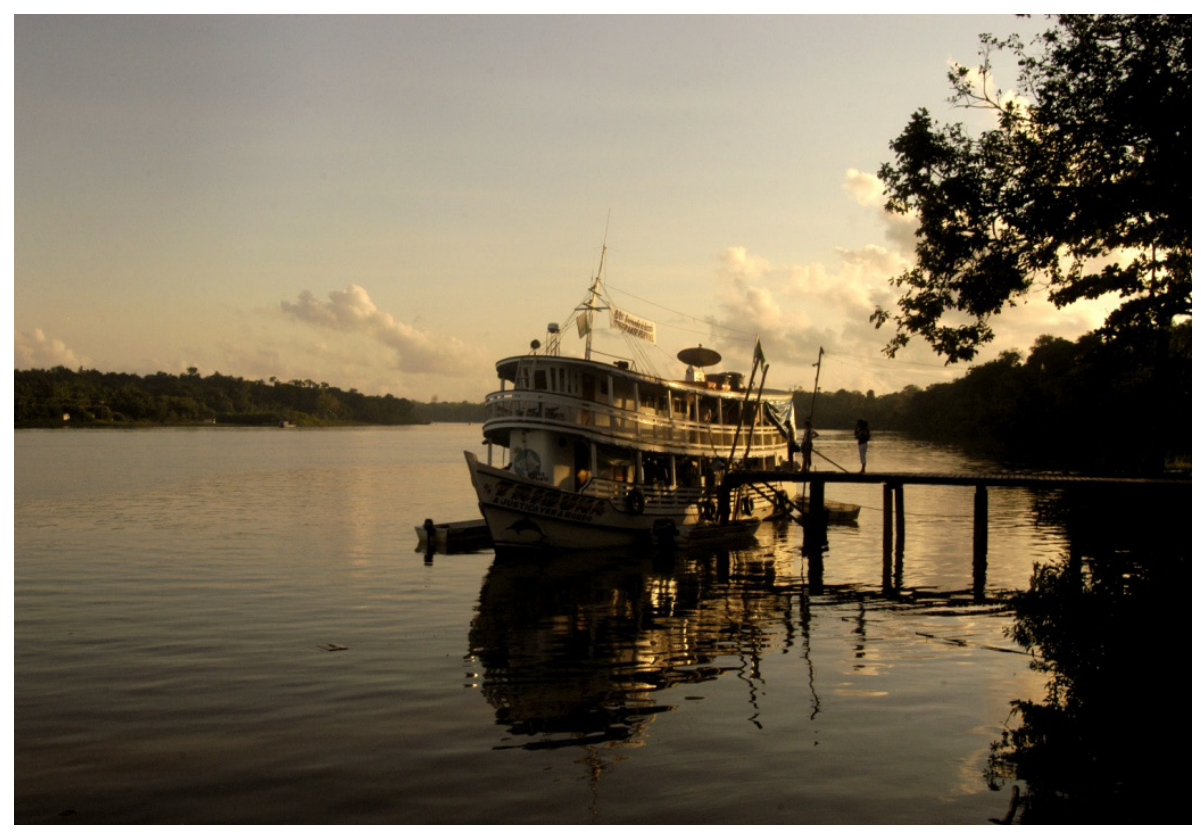

Author of image: Douglas Engle

\section{A 'Tesco Law' and 'Alternative Business Structures' (ABSs): Private Planning of Rural Legal Services}

The structure of private practice in rural areas is heavily influenced, though not wholly dominated, by market forces. In the 1980s the Access to Justice in Rural Britain Project mapped the market for rural legal services in the UK and identified gaps in provision that were more related to areas of work than geographical areas. ${ }^{10}$ The project also mapped the changing structure of law firms and where branch offices were opening and on what basis (see Fig 3).

career. See his address 'Law and Justice outside the CBD' above: (2011) 16(1) Deakin Law Review $1,4$.

${ }^{10}$ Kim Economides and Mark Blacksell, 'Access to Justice in Rural Britain: Final Report (1987) 16(4) Anglo-American Law Review 353; Mark Blacksell, Kim Economides and Charles Watkins, Justice Outside the City: Access to Legal Services in Rural Britain (Longman, 1991); Jon Johnsen, 'Rural Justice: Country Lawyers and Legal Services in the United States and Britain' (1992) 17 Law and Social Inquiry 415; Charles Watkins, Mark 


\section{Fig 3 Branch Office system of Solicitors' Offices in Devon and Cornwall}

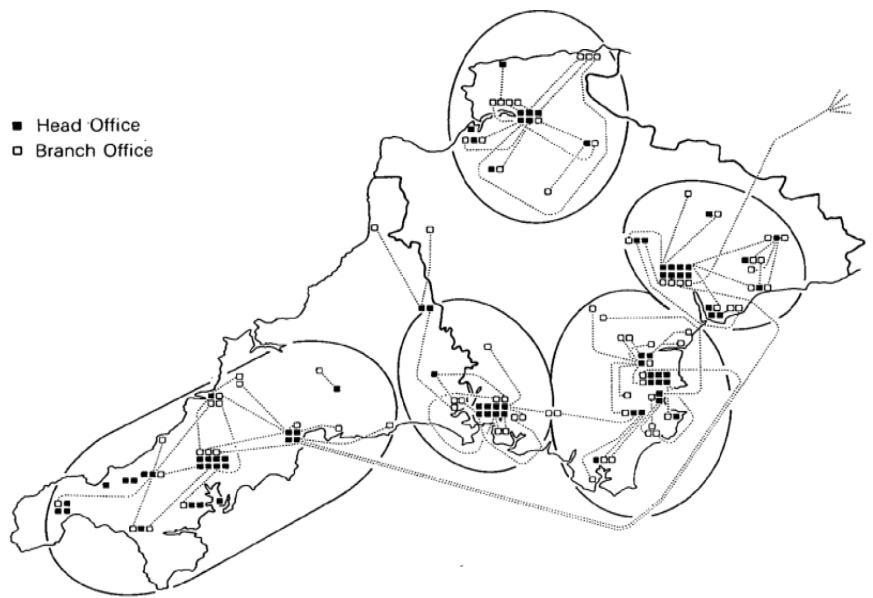

One of the research findings of the Access to Justice in Rural Britain Project was that country lawyers had different attitudes to changes liberalising the legal services market. These largely correlated with age: older lawyers approaching retirement felt unable to survive competition whilst younger lawyers and those prepared to embrace technology felt they could. ${ }^{11}$ It is also clear that rural legal needs have been met by a variety of providers, not all of whom are fully qualified lawyers. ${ }^{12}$ More recently the Legal Services Act 2007 promises to further open up the market for legal services in the UK with the introduction of 'alternative business structures' (ABSs) that will become a reality from 2011 .

Blacksell and Kim Economides, 'The Distribution of Solicitors in England and Wales' (1988) 13 Transactions of the Institute of British Geographers 39.

${ }^{11}$ Kim Economides, 'The Country Lawyer: Iconography, Iconoclasm and the Restoration of the Professional Image' (1992) 19 Journal of Law and Society 115, 116; and in Philip A Thomas (ed), Tomorrow's Lawyers (Blackwell, 1992); Mark Blacksell, Kim Economides and Charles Watkins, 'Country Solicitors: Their Professional Role in Rural Britain' (1987) 25 Sociologica Ruralis $181,184$.

${ }^{12}$ Mark Blacksell et al, 'Citizens Advice Bureaux: Problems of an Emerging Service in Rural Areas' (1990) 24(3) Social Policy and Administration 212, 217. See also Legal Services Commission, Legal Advice: The Way Ahead for Rural and Coastal Communities, Conference Report, 13 March 2007, The Eden Project, Cornwall, UK. 
The headline of 'Tesco Law' (the term used to describe ABSs although it appears the Co-op bank may be the first to take advantage of deregulation) implies that law firms could in future be competing with supermarkets in delivering legal services. Will rural law firms, like the village shop, post office and pub, be threatened by the prospect of new providers entering the legal services market? If the network of supply points is decimated as small rural and provincial law firms go to the wall, will this mean that rural inhabitants suffer a diminution of access to justice? Might legal services be delivered differently, perhaps online, as investment in new technology becomes possible following the economies of scale that mergers and amalgamations of legal (and other) service providers make possible? ${ }^{13}$ Whereas in the past the public sector appeared to be the only way to rectify imperfections in the market - in effect through public investment and subsidy - might in future the private sector be able to meet this need through multi-disciplinary and ABSs? Lawyers in private practice in rural areas are facing new challenges and nowhere is it clear how these challenges will be met. Is it possible to integrate the public and private sectors in a new mixed delivery system ${ }^{14}$

\section{B Planning Rural Legal Services: Rural Proofing?}

A number of approaches are available to reformers seeking to improve the delivery of legal services to rural areas and these tend to focus on either the public or private sector. I have argued for a more integrated approach that links national minimum standards of provision to local legal cultures and suggested that more comparative research be conducted so that there is greater cross-fertilisation between rural delivery systems in Europe, Australia and North America. ${ }^{15}$ I have also advocated the application of 'locationallocation' models ${ }^{16}$ to target legal needs in the most effective and efficient

${ }^{13}$ See David Durham, 'Risk Management Issues Confronting the Rural Solicitor' (Paper Presented at the Regional Legal Practitioners' Workshop, University of Southern Queensland, 23 October 2009); Law Council of Australia, Recruitment and Retention Working Group, 'Recruitment and Retention of Legal Practitioners to Rural, Regional and Remote Areas Strategy' (Discussion Paper) (September 2009) Law Council of Australia <http://www. lawcouncil.asn.au/shadomx/apps/fms/fmsdownload.cfm?file_uuid=6C3EC57C-1E4F-17FAD225-445270E49D9A\&siteName=lca $>$.

${ }^{14}$ Economides, above n 1, 261; Kim Economides and Bryant Garth, 'The Determination of Legal Services Policy in the United Kingdom and United States of America' (1984) 2(4) Environment and Planning C: Government and Policy 445.

${ }^{15}$ See Blacksell, Economides and Watkins, above n 10, ch 7; Economides, above $\mathrm{n} 6$.

${ }^{16}$ These mathematical models identify the optimal location for a service with reference to the minimum total or average distance to consumers. See further Blacksell, Economides and Watkins, above n 10, 191-2. 
manner possible when providing public services such as courts, advice centres and community law centres. Such techniques could also be applied in the private sector by emergent ABSs, as could new technology. ${ }^{17}$ There is a need for research to be conducted nationally and internationally that takes on board the lessons of 'local legal cultures' but at the same time proactively seeks to address the problems of marginal groups that may be excluded by the dominant local culture. Women, youth, the immobile and other 'at risk' clients might benefit from telephone, internet and peripatetic legal services. ${ }^{18}$ Research needs to measure 'friction of distance' in legal service provision. ${ }^{19}$

Policy on legal service provision needs to be subject to 'rural proofing'. This should result in better decision-making, improved communication, stronger relationships and greater capacity of rural interest groups. 'Rural proofing' in the UK involves subjecting all policy to scrutiny over a wide range of topics. Such scrutiny would include asking focused questions relating to: service provision and availability (will the policy affect the availability of public and private services?); delivery costs (will the cost of delivery be higher in rural areas where clients are more widely dispersed and economies of scale can be harder to achieve?); accessibility and infrastructure (will the policy affect travel needs or the ease/cost of travel?); communications (does the policy rely on communicating information to clients?); economies (will the policy impact on rural businesses, including the self-employed?) and disadvantage (will the policy target disadvantaged people or places?). ${ }^{20}$ The idea has also been applied in New Zealand but to date there has been no academic research analysing the efficacy of 'rural proofing'. ${ }^{21}$

\footnotetext{
${ }^{17}$ Kim Economides and Andrew Clark, 'Technology and the Transformation of Contemporary Legal Practice' in Giorgio Piva and Federico Spantigatti (eds), Nuovi Moti Per la Formazione del Diritto (CEDAM, 1988) 565.

${ }^{18}$ Research confirms that vulnerable groups exist in rural communities yet does not always identify ways in which their problems may be overcome. See Lisa Pruitt, 'The Forgotten Fifth: Rural Youth and Substance Abuse' (2009) 20 Stanford Law and Policy Review 359; Lisa Pruitt, 'Gender, Geography and Rural Justice' (2008) 23 Berkeley Journal of Gender, Law and Justice 338.

${ }^{19}$ Blacksell, Economides and Watkins, above n 10, 16.

${ }^{20}$ See, eg, Local Government Improvement and Development, Rural Proofing <http://www. idea.gov.uk/idk/core/page.do?pageId=300459>; East of England Development Agency, Rural Proofing $<$ http://www.eeda.org.uk/rural-proofing.asp $>$.

${ }^{21}$ Ministry of Agriculture and Forestry (NZ), Rural Proof Your Policy: A Best Practice Guide for Policy Advisers (2010) <http://www.maf.govt.nz/news-resources/publications.aspx?title= Rural\%20Proof\%20Your\%20Policy:\%20A\%20best $\% 20$ practice $\% 20$ guide $\% 20$ for $\% 20$ policy $\% 20$ advisers $>$.
} 


\section{CONCLUSION}

Legal services in rural areas remain problematic, partly because the analytical tools at our disposal remain limited and stuck in simplistic dualities such as that of 'insiders' versus 'outsiders'. Perhaps our biggest challenge is to imagine how rural society with scattered, isolated and dispersed populations can build a sense of 'community' coherent enough to found collective, structural legal action of the kind developed by urban law centres. Are 'strategic' approaches possible in rural areas? Is it possible to develop a politics of law literally outside the 'polis'?

${ }^{22}$ See further Mark Blacksell, A Clark and Kim Economides, 'Legal Services in Rural Areas: Problems of Access and Local Need' (1988) 12(1) Progress in Human Geography 47. 